\title{
Automatic Warning System for Weather Station Power Supply
}

\author{
Mumtazanisa Fairuzen ${ }^{1}$, Angga Rusdinar ${ }^{2 *}$, Fiky Yosef Suratman ${ }^{3}$, Denny Darlis ${ }^{4}$ \\ ${ }^{1,2,3}$ School of Electrical Engineering, Telkom University, Bandung, 40287, Indonesia \\ ${ }^{4}$ School of Applied Science, Telkom University, Bandung, 40287, Indonesia \\ ${ }^{1}$ mumtazfairz@student.telkomuniversity.ac.id, ${ }^{2 * a n g g a r u s d i n a r @ t e l k o m u n i v e r s i t y . a c . i d, ~}$ \\ ${ }^{3}$ fysuratman@telkomuniversity.ac.id, ${ }^{4}$ dennydarlis@ @elkomuniversity.ac.id
}

\author{
Accepted 30 August 2021
}

Approved 23 September 2021

\begin{abstract}
Weather observation is one of the important factors in agriculture. Data from weather observations can be used for various things, including to predict future risks due to these weather conditions. An Automatic Weather Station (AWS) is needed to read weather conditions continuously. Some of the devices that will be built for the AWS system are data communication, sensors, and power supply. AWS is usually installed in certain areas where there is no power source. Hence, it takes a power supply system that can stand alone and has a security system that can monitor the components connected to the system in real time.This research successfully designed a power supply system for a weather station that is equipped with current and voltage measurement features for its load as well as a warning system feature in case of interference on GSM SIM900based Weather Station. Based on the results of the study the system using solar cell modules has an efficiency of $14,1 \%$ and is supported with the help of batteries that can be recharged through solar energy. Using the INA219 sensor to measure the voltage and load current connected to devices that have an error percentage value of less than $1 \%$, the data is then uploaded to Thingspeak. Testing of warning systems at the Weather Station is conducted using Magnetic reed sensors capable of detecting changes when the separation distance between the sensor and other magnets is more than $3 \mathrm{~cm}$.
\end{abstract}

Index Terms-GSM; INA219; Magnetic Reed; Power Supply; SMS; Weather Station

\section{INTRODUCTION}

Observation of weather elements is necessary for human well-being and needs. The observed weather elements will be used as material to predict the weather in the future. This weather element data is very useful to know the climatologist of an area, so that humans can take advantage of these weather conditions according to the needs of each party. Weather data can also be used to reduce or even avoid the risk of bad weather [1].. The data to be recorded are temperature, light intensity, humidity, air pressure, wind direction, wind speed and rainfall. Everything that has been recorded by the Weather Station will be stored in the form of data. Weather station observation system (WS) has been developed for quite a long time in developed countries, but the price is quite expensive, therefore it is still very limited to use in Indonesia [2].

The Weather Station operating system is designed as a detection of changes to the sensors that have been determined to obtain weather forecast materials and recorded data will be sent to the station center using a data communication network system. Then the Weather Station device needs to get enough power to power up its sensors. It gets the power source from solar cell, since the sun produced more energy than we will ever need then solar energy is the most reliable source of power for sensors in weather station. Thus, the energy absorbed will be stored in the battery. In its design, this system utilizes one of the renewable energies that is solar energy by using solar cells. These renewable energy resources depend on weather conditions. Therefore, if bad weather occurs then this system cannot function, and renewable electricity is not stored. There needs to be a battery as a storage area for electrical energy generated from solar cells [3]. In previous research weather stations using solar cells as power supplies have the advantage of not only being able to cut spending but also make it easier to monitor systems in areas with resources that are not easily accessible for a long time. The use of solar cells also includes an environmentally friendly design [4].

Previous research has not featured voltage and current monitoring on loads, and there is no safety warning system at the Weather Station. Thus, research on our research is the power source for weather stations that have automatic security systems. The research added features to monitor the load of the Weather Station on the first node (rainfall sensor, wind direction and wind speed) and the second node (temperature, humidity, air pressure and light intensity sensors), the measurement results can be accessed on ioT (Internet of Things) platforms. Weather Station automatic security system is intended in the form of information in the event of theft or interference in both the solar cell module and the panel box door by utilizing magnetic reed sensors and sent via SMS in real-time.

In previous research, it has been done to create a GSM-based home automation system by sending data 
via SMS that can only be intended for active and registered numbers only. The use of GSM in the study because the GSM security infrastructure is reliable, can provide maximum reliability so that outsiders cannot monitor the information sent or received [5]. Therefore, this study uses gsm architecture in sending warning notifications about weather station security in the form of SMS (Short Message Service) to phone numbers registered on the system.

\section{METHOD}

\section{A. Weather Station}

A weather station is a device that collects data related to weather and environment using various and different sensors. This tool applies different types of sensors that use all the parameters that can be measured. Weather Station observation system (WS) has been developed long enough in developed countries, but the price is quite expensive, so it is still very limited to use in Indonesia [6].

This weather station system measures environmental parameters such as temperature, wind direction, wind speed and others using a variety of sensors and there is a security system on the Weather Station that will send notifications in case of obstacles such as stolen solar panels or panel boxes that are forcibly opened on the weather station system [6].

\section{B. Power Supply}

A power supply system is the most important component in an electrical circuit. If the electrical energy produced is not stored, it should be used immediately after it is generated. To increase the utilization of energy produced by the existence of an energy storage system [3]. Energy storage systems can use rechargeable batteries, this component can convert chemical energy into electrical energy [7].

\section{Photovoltaic Solar Cell}

Energy is one of the resources that are important for human life, but non-renewable resources will run out. Now, solar energy is widely utilized around the world. The development of products utilizing photovoltaic solar cells demonstrates the importance of conserving energy as well as awareness of the importance of the role of renewable energy as well as photovoltaic solar cells producing clean energy that is very beneficial and does not damage the environment [8].

Photovoltaic (PV) is a system or direct way to convert solar radiation or foton into electrical energy. This system utilizes the principle of photovoltaic effect, which is where a photovoltaic cell can absorb light energy and convert it into electrical energy. This energy is interpreted as a phenomenon of the emergence of electrical voltage due to the contact of two electrodes connected with the solid or liquid system when obtaining light energy [9]

The main advantage for weather station using solar cell that it can provide enough energy consumption for long periods of time. In this research we use 20WP solar cell module.

\section{GSM}

GSM (Global System for Mobile Communication) was an idea that emerged from the cell-based portable radio framework at bell laboratories in the mid-1970s and GSM was the name of an institution established in 1982 to create a typical European mobile phone standard [10].

GSM is now the most well-known standard for mobile phones in the world developed to gain extensive capabilities for voice services as well as short message (SMS) services. This GSM application can only accept SIM cards (Subscriber Identity Module) and operates through a subscription to a mobile operator [11].

\section{- $\quad$ GSM SIM900}

GSM SIM900 GPRS is a GSM modem that can be used with Arduino Uno. This module can perform its functions as in other mobile phones, send messages, make, or receive calls and connect with GPRS, TCP/IP and others thus allowing this module to be integrated for many IoT projects. This module uses AT Command as its command information [12].

TABLE 1. GSM SIM900 SPECIFICATION

\begin{tabular}{|c|c|}
\hline Specification & GSM SIM 900 \\
\hline Network & $\begin{array}{c}\text { quad-band } 850 / 900 / \\
1800 / 1900 \mathrm{MHz}\end{array}$ \\
\hline GPRS Class & Class $10 / 8$ \\
\hline $\begin{array}{c}\text { GPRS mobile station } \\
\text { class }\end{array}$ & Class B \\
\hline Dimension & $24 \times 24 \times 3 \mathrm{~mm}$ \\
\hline Weight & $3.4 \mathrm{~g}$ \\
\hline Control Via & AT-Command (GSM \\
& $07.07,07.05$ and \\
& SIMCOM enhanced AT \\
& Command) \\
\hline Output Voltage & $3.4 \mathrm{~V}-4.5 \mathrm{~V}$ \\
\hline Temperature & $-40^{\circ}-85^{\circ} \mathrm{C}$ \\
\hline
\end{tabular}

\section{- $\quad G P R S$}

General Packet Radio Service (GPRS) it is a new set of GSM-bearer services that provide packet mode transmission in GSM networks, as well as cooperate with external data packet networks. One of the standout and important features of this GPRS is that the device's handheld device is always connected to the internet, so there is no dial-up connection that must be completed for its data access. GPRS users will be able to send and receive end-to-end data transfer mode packages. GPRS is divided into two categories [13].

1. POINT TO POINT (PTP)

2. POINT TO MULTIPOINT (PTM)

- $\quad S M S$ 
Short Message Service (SMS) is a technology that can exchange (transmit) messages through mobile devices such as mobile phones. Messages that have been sent from the sender's phone are stored in a short message (SMS center) which will then be forwarded to the recipient's phone. SMS messaging services have no more than 160 characters [14].

\section{E. Internet of Things}

The IoT platform used is Thingspeak, Thingspeak is a web based open IoT API platform. Thingspeak serves to store data from various 'IoT applications' and display their output in the form of graphs. It requires help from an internet connection to communicate through Thingspeak which serves as a 'data packet'. Thingspeak can work on data from sensors connected to the host microcontroller.

\section{SYSTEM REALIZATION}

\section{A. Function Diagram System}

To achieve our goal, we designed a function diaphgram shown below

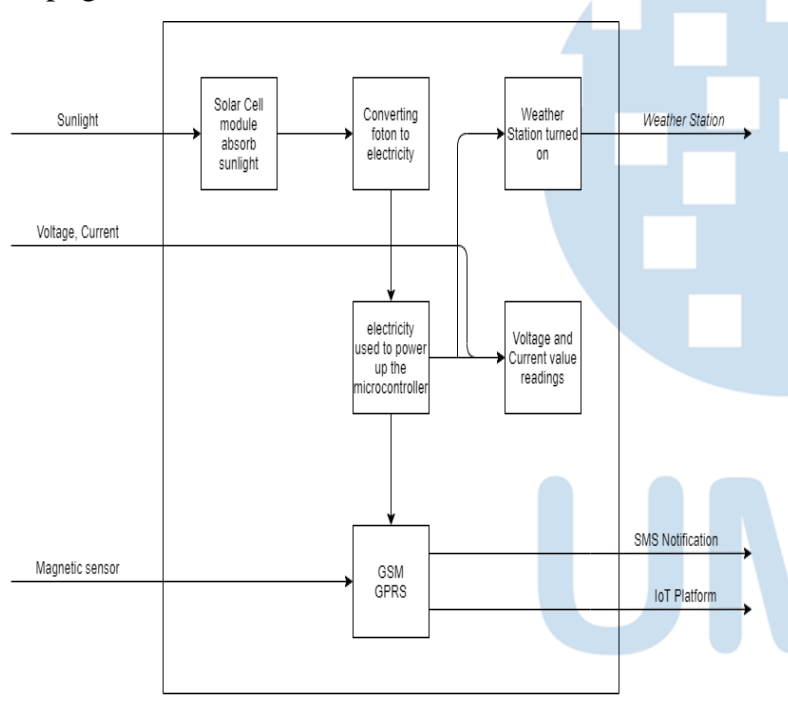

Fig. 1. Function Diagram System

Power supply system with sun radiation source using solar cell and there are sensors that can monitor current and load voltage and the measurement results will be displayed on the IoT platform. Used magnetic sensors placed in two places, namely on the solar panel and on the door of the Weather Station box as a warning system that will notify alerts when solar panel is stolen, or weather station control box doors are forcibly opened using GSM module as data communication.

With this system is expected to be an effective solution as a load monitoring system on the Weather Station and Weather Station security warning system.

The working principles of this system are:

1. The initial stage of the work of this system is the input of energy produced by solar cells.

2. Then, the incoming energy will be stored in the solar battery.
3. The battery will function as a power source of the overall work of the Weather Station system.

4. The sensor can detect voltage and current on the sensor load contained in the sensor.

5. Sensor load detection results will appear on Thingspeak.

6. If the solar panel does not exist or the panel box is forcibly opened it will send text message alert to the registered user number.

\section{B. Hardware Design System}

The design of our power supply system with warning system for Weather Station is shown in Fig. 1. The architecture consists of solar cell module, solar charge controller, 12V 7Ah battery, INA219 sensor, Magnetic reed, Arduino Uno and GSM SIM900 module.

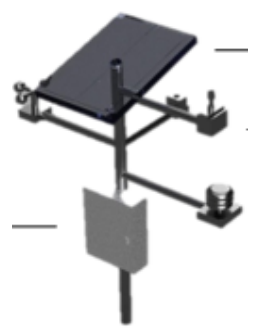

Fig. 2. Hardware Design System

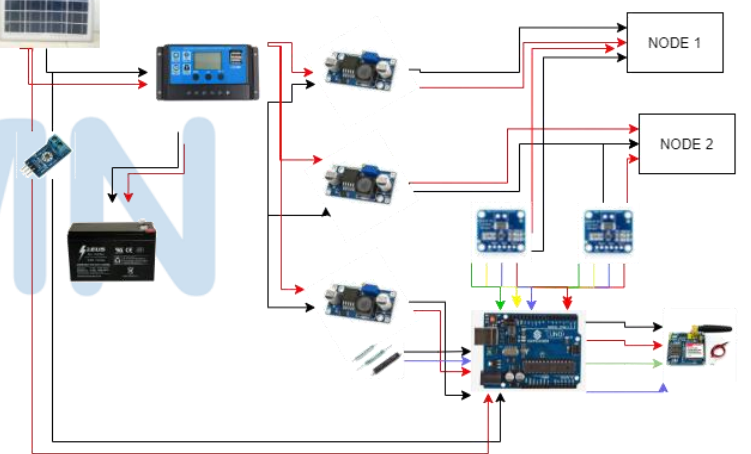

Fig. 3. Wiring Design System

\section{Software Design System}

The picture below shows as steps of a process in sequential order, known as flowchart. 


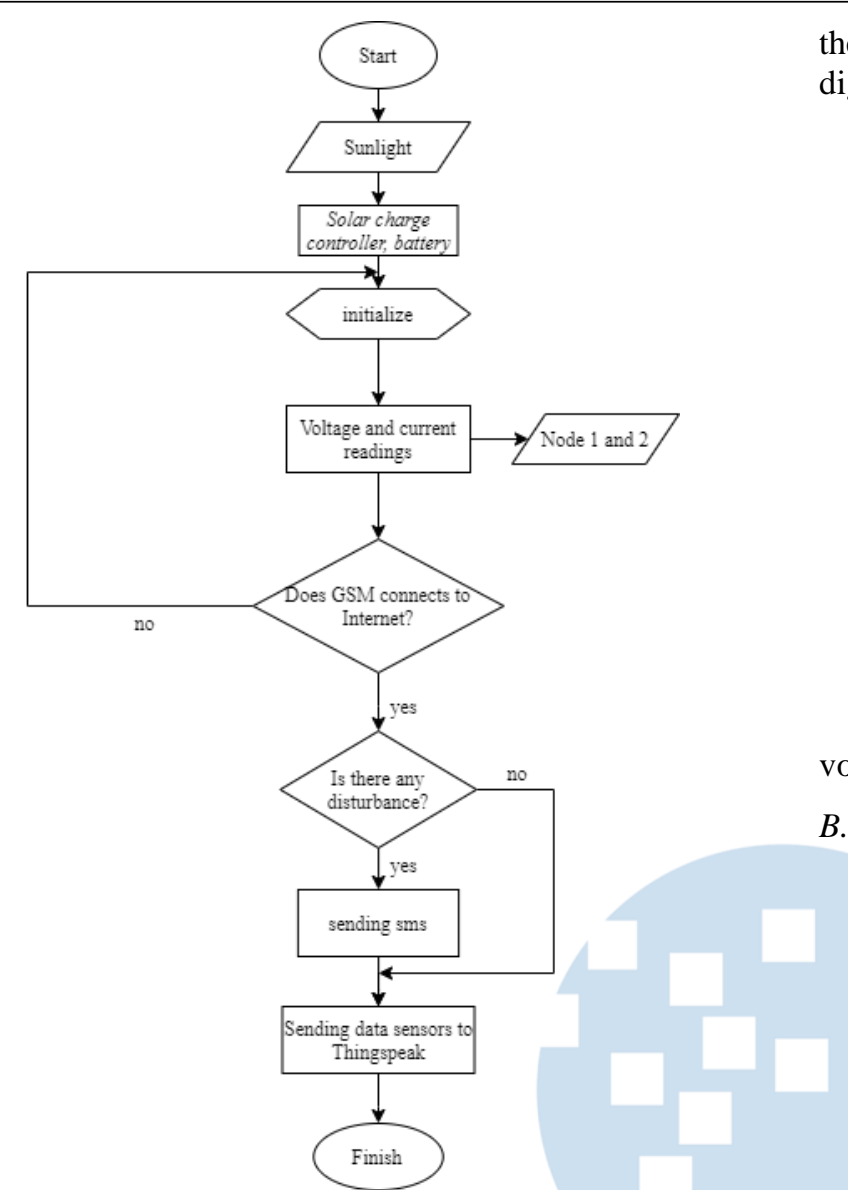

Fig. 4. Software Design System (Flowchart)

Starting with charging the battery using a solar panel with an SCC controller. Batteries connected to SCC will activate the Weather Station and GSM systems as load monitoring systems and security systems that then wait for the connection network to connect to the internet. When connected to the internet, GSM will process the data of load measurement parameters on the Weather station which will then be sent to the IoT (Thingspeak) platform. In Thingspeak will appear data on load measurement parameters on the Weather station system. If the solar cell module is detached from the weather station pole or the door is opened by other than the management then GSM will send warning notifications in the form of sms (text message).

\section{RESUlT AND DISCUSSION}

In this chapter will be discussed about the results of testing and analysis of the realization of tools in accordance with the design of the system.

\section{A. Voltage Testing on 20 WP Solar Cell Module without Load}

The voltage test of the 20 WP solar cell module aims to determine the output voltage of the panel that matches the specifications on the panel used.

The test was conducted five times from June 12 to June 16, 2021, from $08.00-18.00$. The tool used to see the output voltage of the solar cell module is to use a digital multimeter (Sanwa CD800a).

Average Voltage on 20WP Solar

Cell Module without Voltage

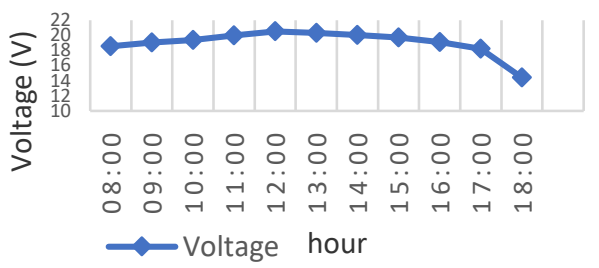

Fig. 5. Average Voltage on 20 WP Solar Cell Module without Voltage

Based on the test results, the average maximum voltage is $20.52 \mathrm{~V}$ at $12: 00$.

B. Voltage and Current Testing on a 20 WP Solar Cell Module and 12 V 7Ah Battery

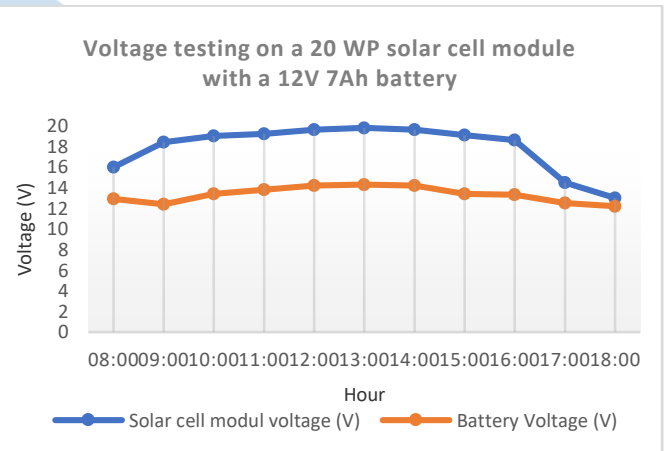

Fig. 6. Voltage Testing on 20 WP Solar Cell Module and 12 V 7 Ah Battery

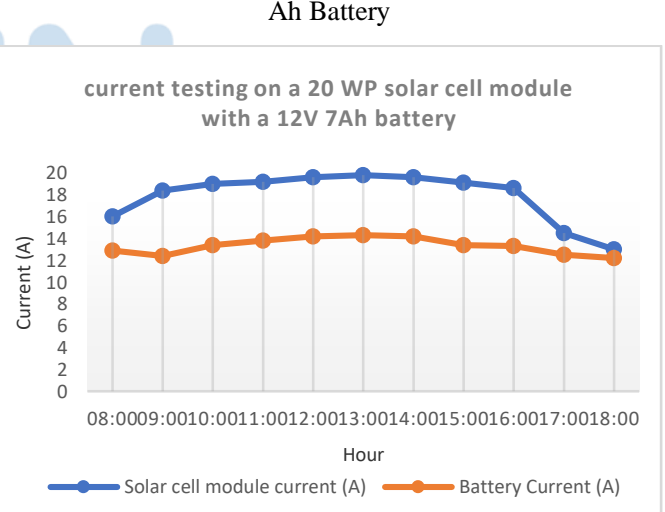

Fig.7. Current Testing on $20 \mathrm{WP}$ Solar Cell Module and $12 \mathrm{~V} 7 \mathrm{Ah}$ Battery

The most efficient battery charging time is when 12:00 - 14:00 with a voltage that can reach $14.30 \mathrm{~V}$. Because at that hour the solar cell module gets the most light intensity.

\section{Efficiency Testing on Solar Cell Module}

This test aims to determine the efficiency of the 20 WP solar cell module with the influence of light intensity.

$$
\mathrm{D}_{\text {(Efficiency) }}=\frac{P \max }{I \times A} \times 100 \%
$$


$\mathrm{nb}:$

$P_{\max } \quad=$ Power in the cell (Watt)

$I=$ Sunlight Intensity $\left(\mathrm{watt} / \mathrm{m}^{2}\right)$

$A=$ Area of solar cell module $\left(\mathrm{m}^{2}\right) \rightarrow 0,155 \mathrm{~m}^{2}$

Solar Cell Module Efficiency

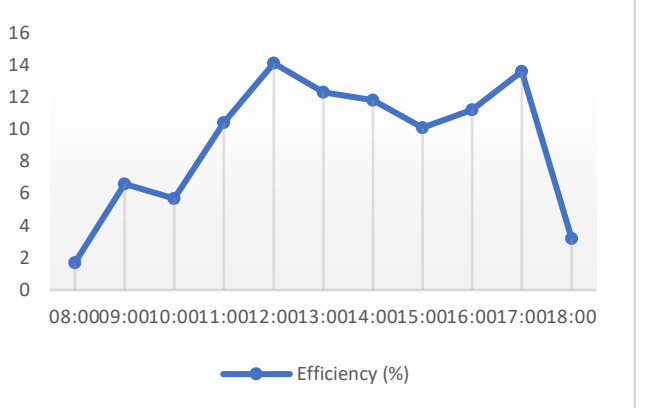

Fig.8. 20 WP Solar Cell Module Efficiency

The graph above shows the efficiency of the 20WP solar cell module measured from 08:00 to 18:00. The maximum efficiency obtained by solar modules reaches $14 \%$ while the minimum efficiency is less than $2 \%$.

\section{Testing on INA219 Sensor}

The INA219 sensor test aims to find out if the sensor is functioning properly on load measurements on a weather station system that will be compared to the current and voltage of a multimeter.

Error Value $=\frac{\mid \text { Multimeter Measurement-INA219|}}{\text { Multimeter Measurement }} \times 100 \%$ (2)

TABLE 2. INA219 VOLTAGE AND CURRENT TESTING ON NODE 1

\begin{tabular}{|c|c|c|c|c|c|c|}
\hline & & & DDE I & & & \\
\hline & VOLTA & & & CURRE & (MA) & \\
\hline TEST NO. & NA219 & $\begin{array}{c}\text { LTIMET } \\
\text { ER }\end{array}$ & (\%) & NA219 & $\begin{array}{l}\text { MULTI } \\
\text { METER }\end{array}$ & $\operatorname{ROR}(\%)$ \\
\hline 1 & 6.16 & 6.16 & 0 & 256.3 & 255.3 & 0.39 \\
\hline 2 & 6.10 & 6.16 & 0.97 & 256.3 & 253.7 & 1.02 \\
\hline 3 & 6.16 & 6.16 & 0 & 246,6 & 243.0 & 1.48 \\
\hline 4 & 6.16 & 6.16 & 0 & 251.7 & 249.6 & 0.84 \\
\hline 5 & 6.16 & 6.16 & 0 & 256.3 & 254.9 & 0.54 \\
\hline & ERAGE & & 0.19 & $\mathrm{AVE}$ & & 0.85 \\
\hline
\end{tabular}

As shown in the table above, it indicates that the INA219 sensor can read the voltage quite accurately with a percentage error value of $0.19 \%$. As well as the percentage for the current reading of $0.85 \%$.

TABLE 3. INA219 VOLTAGE AND CURRENT TESTING ON NODE 2

\begin{tabular}{|c|c|c|c|c|c|c|}
\hline \multicolumn{7}{|c|}{ NODE 2} \\
\hline \multirow[b]{2}{*}{ TEST NO. } & \multicolumn{2}{|c|}{ VOLTAGE $(\mathrm{V})$} & \multirow{2}{*}{$\begin{array}{l}\text { EROR } \\
(\%)\end{array}$} & \multicolumn{2}{|c|}{ CURRENT (MA) } & \multirow[b]{2}{*}{ ROR (\%) } \\
\hline & NA219 & $\begin{array}{c}\text { LTIMETE } \\
\mathrm{R}\end{array}$ & & NA219 & $\begin{array}{l}\text { MULTI } \\
\text { METER }\end{array}$ & \\
\hline 1 & 8.16 & 8.16 & 0 & 78.2 & 78 & 0.25 \\
\hline 2 & 8.16 & 8.16 & 0 & 78.4 & 77.9 & 0.64 \\
\hline 3 & 8.17 & 8.16 & 0.12 & 77.9 & 78.2 & 0.38 \\
\hline 4 & 8.15 & 8.16 & 0.12 & 78 & 77.8 & 0.25 \\
\hline
\end{tabular}

\begin{tabular}{|l|l|l|l|l|l|l|}
\hline 5 & 8.16 & 8.16 & 0 & 77.9 & 77.6 & 0.38 \\
\hline \multicolumn{3}{|c|}{ AVERAGE } & 0.048 & AVERAGE & 0.38 \\
\hline
\end{tabular}

The table above, shows the result of current and voltage measurements from INA219 for node 2 . The INA219 sensor that reads voltage and current is accurate, which has an error percentage value of $0.048 \%$ for voltage and $0.38 \%$ for current.

\section{E. Measurement Testing on Magnetic Reed Senor}

The test aims to make sure that sensor could give the right output, to know the condition of the sensor within a certain range as well as the sending time interval for the security system on the solar cell module and the control box. To run the test, we used digital multimeter (Sanwa CD800a).

This test is done at intervals of distance of $0 \mathrm{~cm}$ to $10 \mathrm{~cm}$.

TABLE 4. Measurement Testing on Magnetic ReED SENSOR

\begin{tabular}{|c|c|c|c|}
\hline $\begin{array}{c}\text { Testing } \\
\text { no. }\end{array}$ & $\begin{array}{c}\text { Distance } \\
(\mathbf{c m})\end{array}$ & $\begin{array}{c}\text { Voltage } \\
(\mathbf{V})\end{array}$ & Output \\
\hline 1. & 0 & 0 & $O N$ \\
\hline 2. & 1 & 0 & $O N$ \\
\hline 3. & 2 & 0 & ON \\
\hline 4. & 3 & 0 & $O N$ \\
\hline 5. & 4 & 0.01 & $O F F$ \\
\hline 6. & 5 & 0.12 & $O F F$ \\
\hline 7. & 6 & 0.17 & $O F F$ \\
\hline 8. & 7 & 0.2 & $O F F$ \\
\hline 9. & 8 & 0.23 & $O F F$ \\
\hline 10. & 9 & 0.25 & $O F F$ \\
\hline 11. & 10 & 0.3 & $O F F$ \\
\hline
\end{tabular}

\section{F. Warning System via SMS}

Sending the notification alert sms on Weather Station on verified number by system. To make the test work out, we used Telkomsel as system provider. Data were observed for a week from June $28^{\text {th }}$ to July $30^{\text {th }}$ with five data each for warning system on solar cell module and warning system on control box.

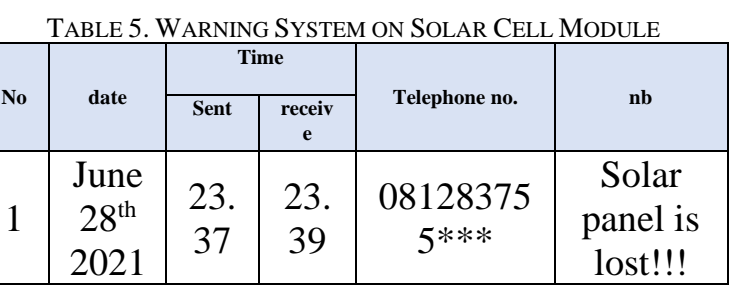




\begin{tabular}{|c|c|c|c|c|c|}
\hline 2 & $\begin{array}{c}\text { July } \\
7^{\text {th }} \\
2021\end{array}$ & $\begin{array}{l}12 . \\
09\end{array}$ & $\begin{array}{l}12 . \\
11\end{array}$ & $\begin{array}{c}08128375 \\
5 * * *\end{array}$ & $\begin{array}{c}\text { Solar } \\
\text { panel is } \\
\text { lost!!! }\end{array}$ \\
\hline 3 & $\begin{array}{c}\text { July } \\
21^{\text {st }} \\
2021\end{array}$ & $\begin{array}{l}09 . \\
24\end{array}$ & $\begin{array}{l}19, \\
25\end{array}$ & $\begin{array}{c}08228495 \\
3 * * *\end{array}$ & $\begin{array}{c}\text { Solar } \\
\text { panel is } \\
\text { lost!!! }\end{array}$ \\
\hline 4 & $\begin{array}{c}\text { July } \\
24^{\text {th }} \\
2021\end{array}$ & $\begin{array}{l}20 . \\
56\end{array}$ & $\begin{array}{l}20 . \\
57\end{array}$ & $\begin{array}{c}08228495 \\
3 * * *\end{array}$ & $\begin{array}{c}\text { Solar } \\
\text { panel is } \\
\text { lost!!! }\end{array}$ \\
\hline 5 & $\begin{array}{c}\text { July } \\
26^{\text {th }} \\
2021\end{array}$ & $\begin{array}{l}13 . \\
12\end{array}$ & $\begin{array}{l}13 . \\
12\end{array}$ & $\begin{array}{c}08228495 \\
3 * * *\end{array}$ & $\begin{array}{l}\text { Solar } \\
\text { panel is } \\
\text { lost!!! }\end{array}$ \\
\hline
\end{tabular}

TABLE 6. WARNING SYSEM ON CONTROL BOX

\begin{tabular}{|c|c|c|c|c|c|}
\hline \multirow{2}{*}{ No } & \multirow{2}{*}{ Date } & \multicolumn{2}{|c|}{ Time } & \multirow{2}{*}{ Telephone No. } & \multirow[b]{2}{*}{ nb } \\
\hline & & Sent & $\begin{array}{c}\text { Recei } \\
\text { ve }\end{array}$ & & \\
\hline 1 & $\begin{array}{c}\text { July } 24^{\text {th }} \\
2021\end{array}$ & $\begin{array}{l}15 . \\
00\end{array}$ & $\begin{array}{l}15 . \\
01\end{array}$ & $\begin{array}{c}0812837 \\
55^{* * * *}\end{array}$ & $\begin{array}{c}\text { Door } \\
\text { opened } \\
!\end{array}$ \\
\hline 2 & $\begin{array}{c}\text { July } 26^{\text {th }} \\
2021\end{array}$ & $\begin{array}{l}13 . \\
00\end{array}$ & $\begin{array}{l}13 . \\
02\end{array}$ & $\begin{array}{c}0812837 \\
55 * * *\end{array}$ & $\begin{array}{c}\text { Door } \\
\text { opened } \\
!\end{array}$ \\
\hline 3 & $\begin{array}{c}\text { July } 29^{\text {th }} \\
2021\end{array}$ & $\begin{array}{l}14 . \\
20\end{array}$ & $\begin{array}{l}14 . \\
23\end{array}$ & $\begin{array}{c}0822849 \\
53 * * *\end{array}$ & $\begin{array}{c}\text { Door } \\
\text { opened } \\
!\end{array}$ \\
\hline 4 & $\begin{array}{c}\text { July } 30^{\text {th }} \\
2021\end{array}$ & $\begin{array}{l}20 . \\
56\end{array}$ & $\begin{array}{c}20 . \\
57\end{array}$ & $\begin{array}{c}0822849 \\
53 * * *\end{array}$ & $\begin{array}{c}\text { Door } \\
\text { opened } \\
!\end{array}$ \\
\hline 5 & $\begin{array}{c}\text { July } 30^{\text {th }} \\
2021\end{array}$ & $\begin{array}{l}19 . \\
31\end{array}$ & $\begin{array}{l}19 . \\
31\end{array}$ & $\begin{array}{c}0822849 \\
53 * * *\end{array}$ & $\begin{array}{c}\text { Door } \\
\text { opened } \\
!\end{array}$ \\
\hline
\end{tabular}

\section{H. System Result}

The picture below is a Weather Station that has been made with a box dimension of $50 \times 20 \times 50 \mathrm{~cm}$, with a pole height of $250 \mathrm{~cm}$ and the dimensions for the solar cell module used are $433 \times 354 \times 17 \mathrm{~mm}$. This weather station is placed behind Building $\mathrm{P}$ of Telkom University's Faculty of Electrical Engineering.
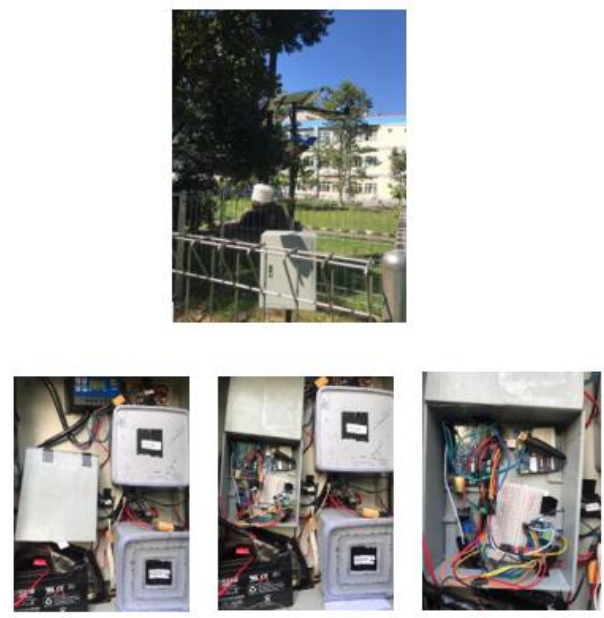

Fig. 10. Power Supply System with Warning System on Weather Station

\section{CONCLUSION}

We conclude that:

1. The system using solar cell module 20WP with the $12 \mathrm{~V} 7 \mathrm{Ah}$ battery as the energy storage. With the highest average Voltage is when 12.00 with $20,52 \mathrm{~V}$ without load. There is also the highest efficiency percentage at 12.00 with $14,1 \%$.

2. Voltage and current measurement by INA219 Sensor are appropriately accurate with the voltage error percentage at $0,19 \%$ and current error percentage at $0,85 \%$ for node 1 . Therefore node 2 have the voltage error percentage at $0,048 \%$ and current error percentage at $0,38 \%$. The result will be sent and show on ThingSpeak using communication module GSM SIM900.

3. The security system is installed under the solar cell module and the Weather Station panel box door can already send a warning notification that there is a theft of components at the Weather Station using GSM SIM900. GSM will send a warning notification when the distance of the cell module with the mast is detached with a minimum distance of $1 \mathrm{~cm}$. Similarly, the weather station panel box door will send a warning notification if the door is open with a distance of at least $1 \mathrm{~cm}$.

4. Warning system will notify by sending sms that have different sending and receiving time, the delay is between 10 seconds to 5 minutes depending on its provider network. 


\section{ACKNOWLEDGMENT}

This work is financially supported by INACOS laboratory research funding. Mumtazanisa Fairuzen is gratefully acknowledged by Mr. Angga Rusdinar during her internship at INACOS Laboratory.

\section{REFERENCES}

W. Sucipto, I. G. A. K. D. Djuni Hartawan, and W. Setiawan, "Rancang Bangun Perangkat Pemantau Cuaca Otomatis Berbasis Mikrokontroler pada Jaringan WLAN IEEE 802.11b," J. SPEKTRUM, vol. 4, no. 2, p. 48, 2018 , doi: 10.24843/spektrum.2017.v04.i02.p07.

[2] M. S. Machfud, M. Sanjaya, and G. Ari, "Rancang Bangun Automatic Weather Station (AWS) Menggunakan Raspberry Pi," vol. 2, no. 2, pp. 78-80, 2016.

[3] D. O. Akinyele and R. K. Rayudu, "Review of energy storage technologies for sustainable power networks," Sustain. Energy Technol. Assessments, vol. 8, pp. 74-91, 2014, doi: 10.1016/j.seta.2014.07.004.

[4] S. J. Raj, A Sundar., Madhumita, M., Hawkinson, "Weather Station Update Using Renewable Energy Source," no. September, 2020, doi: 10.37896/jxu14.5/527.

[5] R. Teymourzadeh, S. A. Ahmed, K. W. Chan, and M. V. Hoong, "Smart GSM based home automation system," Proc. - 2013 IEEE Conf. Syst. Process Control. ICSPC 2013, no. December, pp. 306-309, 2013, doi: 10.1109/SPC.2013.6735152.

[6] R. K. Kodali and S. Mandal, "IoT based weather station," 2017, doi: 10.1109/ICCICCT.2016.7988038.
[7] P. K. Nayak, L. Yang, W. Brehm, and P. Adelhelm, "From Lithium-Ion to Sodium-Ion Batteries: Advantages, Challenges, and Surprises," Angewandte Chemie International Edition. 2018, doi: 10.1002/anie.201703772.

[8] F. Shariff, N. A. Rahim, and H. W. Ping, "Photovoltaic remote monitoring system based on GSM," CEAT 2013 - 2013 IEEE Conf. Clean Energy Technol., pp. 379-383, 2013, doi: 10.1109/CEAT.2013.6775660.

[9] S. Dwisetyowati, "Performa Sel Surya," pp. 653, 2008.

[10] I. Haq, Z. U. Rahman, S. Ali, and E. M. Faisal, "GSM Technology: Architecture, Security, and Future Challenges," Int. J. Sci. Eng. Adv. Technol., vol. 5, no. 1, pp. 70-74, 2017.

[11] "RFID and GSM Based Library Management Sri Ramanujar Engineering College Chennai 600073 and Bharath University Chennai 600 073 Manuscript Info,” vol. 2, no. 9, pp. 283 286, 2014.

[12] Sialee Leekongxue, Li Li, and Tomas Page, "Smart Door Monitoring and Locking System using SIM900 GSM Shield and Arduino UNO," Int. J. Eng. Res., vol. V9, no. 04, pp. 47-52, 2020, doi: 10.17577/ijertv9is040011.

[13] E. Gsm, T. Gsm, T. Gsm-enabled, and T. Gsm, "Samjani2002," pp. 12-15, 2002.

[14] R. Shaw and H. Bosworth, "Short message service (SMS) text messaging as an intervention medium for weight loss: A literature review," Health Informatics J., vol. 18, no. 4, pp. 235-250, 2012, doi: $10.1177 / 1460458212442422$. 